\title{
IMMIGRANT SENSIBILITIES IN TECH WORLDS: Sensing Hate, Capturing Dissensus
}

\author{
SAREETA AMRUTE \\ University of Washington and Data \& Society Research Institute \\ (iD) https:/ / orcid.org/0000-0002-5320-4600
}

The highway traveled east. I left Seattle in my rearview mirror and followed the road's curve toward Microsoft's corporate campus and its belt of smaller satellite firms. The asphalt skimmed a misty lake where eagles perched on streetlamps tracked SUVs like they were salmon coursing below; it deposited me at a strip mall between a bend in the road and a grassy field dotted with grazing horses, whose bridle trails follow pathways laid down by the Coast Salish and Duamish peoples. On this bright June day in 2017, Philip motioned me into a parking spot outside the swinging glass doors of a chain bakery. He would be my guide in this suburban borderland, where Asian coders are valorized as a cheapened alternative to American citizen coders even while they are framed as job-taking aliens.

Philip was in his late forties, with close-cropped, salt-and-pepper hair and an easy, infectious smile. He came to the United States from Taiwan after college and now worked in the technical software division of a Seattle-area hospital. His favorite part of the job was visiting hospital patients to evaluate the system he helped build. Philip had a quiet demeanor and beamed every time he mentioned his wife and two children. Outside the hospital, though, Philip has experienced months of low-level harassment, the kind that the Washington State's Attorney General's Office terms "hate incidents," distinguished from the more serious "hate crimes." 
Hate incidents might include verbal threats, the defacement of property, bullying, inappropriate questions, or even shoves and projectiles. Unlike hate crimes, hate incidents do not fall within the boundaries of what can be prosecuted under the law, a distinction explained to immigrant groups at numerous sessions held by local police departments across Seattle's Eastside. ${ }^{2}$

Immigrants from India and China who work in the Seattle area in software-related businesses have come to terms with increased levels of harassment since Donald Trump rose to national prominence during the 2016 presidential election. This essay depicts these immigrants interacting with the state through community meetings and follows them as they report patterns of harassment that remain unactionable to the police. I trace the entrainment of immigrant senses by elaborating on what Jacques Rancière (2004, 12-13) calls the "distribution of the sensible": the way a particular partition of people, places, and ideas is made to seem self-evident to perception. As I will demonstrate, Rancière's model of dissensus, or the political possibilities inherent in recognizing a distribution of the sensible as particular, fails to account for that which is enunciated but unheeded. Accordingly, I read dissensus against the texture of migrants' experience with hate unavailable for legal action. I call this experience the sensate for the way it enunciates how embodied differences and regimes of value shape politics.

This essay extends Rancière's notion of the distribution of the sensible through a discussion of the racialized capital that "Asian" coding embodies. I offer an account of how the state and immigrants sense across a landscape marked by extrastate authority inherent in corporate landscapes and their attendant manicured commercial domains. Even while immigrant senses are trained to register hate, their reports also register illegible, unactionable events and produce state effects that fall neither within the normal distribution of the sensible nor inside dissensus.

Tech industries and the geographies that surround them often function like a terra nullius in the landscape, an open country unencumbered by regimes of governance. The suburban radii of Microsoft's campuses push farther east economically marginalized, largely white communities who experience this shift with great ambivalence. They benefit from the sales of their newly valuable homes but find themselves simultaneously displaced by tech-economy riches. Indian and Chinese software engineers often serve as the figureheads of these displacements. ${ }^{3}$ At the same time, the successive displacements of Indigenous populations from Seattle and its environs throughout the nineteenth century and the internment of Japanese farmers during the twentieth (Takami 1992; Takaki 1993; Thrush 2007; 
Pearkes 2016) materialize in the way roads, corporate campuses, and strip malls incorporate these pathways of use and erasure. Drawing inspiration from these ongoing erasures as sites of conflict, this essay centers the sites where local and corporate governance collide — what Keller Easterling (2014) calls extrastatecraft: procedures where corporate governance structures both adopt and challenge state structures. These practices materialize in the repeatable and modifiable shapes of the corporate campus, the housing development, and the upscale mall, which become sites of contestation in racializing space, a process that rearticulates the use of space, who moves through it, and the cultural repertoires of landscape (Lipsitz 2007; Easterling 2014).

The spaces created by and alongside Seattle's tech companies are also spaces brought into existence through the statecraft and extrastatecraft of an upper-caste, upper-class South Asian diaspora. Just as these spaces are shaped by Pacific Northwest histories of migration, expulsion, and techno-capitalist sanitization, so too are they shaped by postcolonial Indian repertoires of caste and class exclusion (Subramanian 2015). As Purnima Mankekar (2015) shows in her analyses of affect among Indian migrants in San Francisco, by attending to the border between corporate and state governance in such spaces as community centers, schools, and shopping malls, we can better understand regimes of racial capital and the sensory apparatus of the state as they knit together daily interactions in tech worlds. Here, I pay particular attention to the everyday state-effects produced when immigrants are both victims of and instruments for detecting intolerable acts (Scott 1998; Trouillot 2001; Povinelli 2002; Aretxaga 2012).

I interweave a theory of the senses with that of racial capital to understand shifts in the organization of immigration, race, and value creation. Racial capital describes the foundational necessity of racialized bodies to the creation of value under capitalism, including the way ideas about the characteristics of populations justify current relationships of power (Robinson 2000; see also Leong 2013; Kelley 2015; Hudson 2017; Bhattacharyya 2018). ${ }^{4}$ This essay offers an account of racial capital as it moves across multiple kinds of racial formations. As such, I follow the work of Frantz Fanon (2008), Homi K. Bhabha (1994), Sylvia Wynter (1989), and Alexander Weheliye (2014) in showing how divisions in the category of the human determine categories of human labor. To wit, IT professionals from India and China are both targeted for harassment within a political climate increasingly hostile to immigrants as job takers and separated out as upper class (and within the South Asian context and often for themselves, upper-caste subjects) from other 
Asian immigrants, as well as Latinx, Native, and Black bodies (Lye 2004; Muñoz 2007; Chun 2011; Halewood 2011; Amrute 2020).

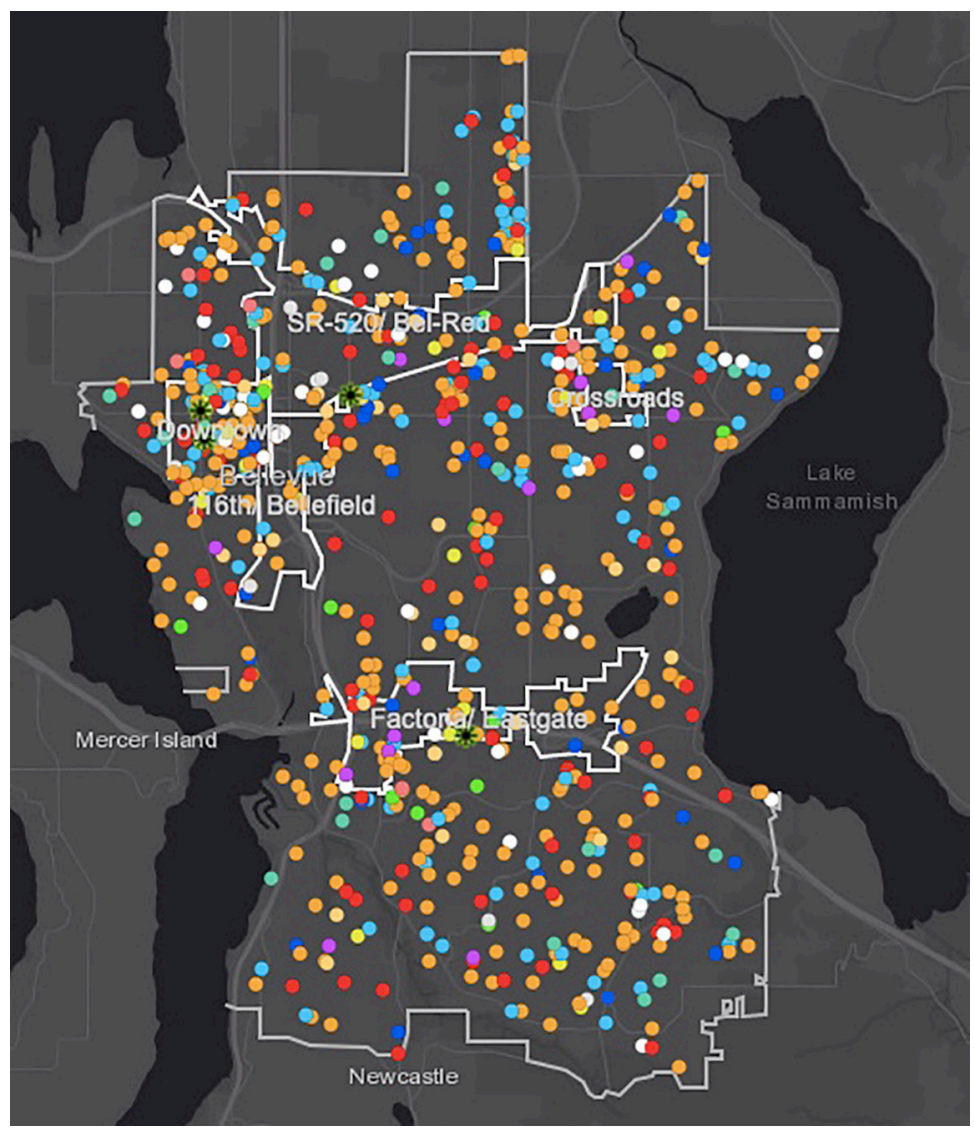

Figure 1. Map of Seattle's Eastside showing tech start-ups. http:// cobgis.maps.arcgis.com/ apps $/$ MapSeries/index.html?appid=7453faf396f144798372f3efofd90fc2.

\section{MANAGING IMMIGRANT REACTIONS TO HATE}

In a middle school gym just north of Salish Flats, students and parents sat in a semicircle around invited speakers: two representatives from the United States' Attorney General's office, a local police chief, a child psychologist, and Amrita, the organizer of this event about responding to hate crimes and the leader of a local community organization for elderly South Asians.

Amrita began the meeting with slides compiled from real incidents that members of her organization and their families had experienced and reported to her. Amrita then asked each of the other guests to speak to what the victim should do in such situations. 
As she spoke, a series of immigrant nightmares flickered across the pulldown portable projector screen: I was told to go back to my own country, how should I respond? I was coming out of a coffee shop in my neighborhood and someone threw coffee in my direction, narrowly missing me. What should I have done? My high schooler was told he was a terrorist, and derogatory things were written on his locker. I was stopped at a traffic light when two men pulled up in a car next to me. They said racist and sexist things, then tailgated me; I was scared and worried for my safety. Everyone had boarded a domestic flight and only I was asked to leave. I was a bystander and I witnessed someone being harassed. I was filling up my car at a gas station; someone came up to me and asked, "Are you Hispanic or Muslim?" I was waiting at a bus stop, when two men jumped out of an SUV with darkened windows and asked me for my immigration papers. They asked, did I have a Green Card or an H-1B? My child was harassed on the school bus and told that, with Donald Trump now elected, she would have to leave the country. What am I to do?

For each scenario, the invited guests offered a strategy catalogue and stressed that the victims needed to decide for themselves which one of these felt most comfortable. The police chief suggested that the incident at the gas station might be deflected. "That sounds like the beginning of a joke," she offered as a response. She went on to claim that animus might not motivate such questions, that people might be curious about things they did not see every day. "Being cagey or suspicious," she declared, "can create tension that doesn't have to be there." The chief proposed answering the question straightforwardly, and then asking, "Why do you want to know?" Yet she also admitted to a difference in the time of Trump. "It is hard," the chief said, "to change people's desires, so we have to work on reducing opportunities for hate crimes to occur." She thinks of hate crimes as an exacerbation of bullying, which she called an "old brain response" resting on ignorance and fear. As she saw it, Trump's election brought to the surface underlying fears and desires that remain difficult to heal. In accounting for changed times, the victim also has to be made aware of what to do if a situation escalated. If our instincts are wrong and the encounter is not friendly, the chief continued, we should say, "I'm dialing 911, I'm not feeling comfortable or safe.” The representatives from the U.S. Attorney General's office added that the victim should carefully avoid engaging in verbal abuse. "Do not have a malicious dialogue," warned one, "then no one can come back and say you were part and parcel to that."

If the senses "hinge" the body to regimes of action (Hirschkind 2006, 29), then this police chief's messages about the everyday immigrant experience with 
hate make immigrants responsible for preventing racial animus from escalating into crime. Such logic indicates a state trying to incorporate immigrants into the norms and practices of American attitudes toward foreignness and its conversational styles. ${ }^{5}$ These disciplinary practices normalize immigrant bodies as the proper repository for national curiosity, even while they formally acknowledge that these questions sometimes mask more malicious intent and anticipate the power of innocent immigrant testimony in scenes of judicial prosecution. In these sessions, the state itself is produced as the interpreter of the acceptable limits of national curiosity. Immigrants must tread carefully, moving through a landscape beset with both innocent curiosity and dangerous hatred.

Police training sessions parcel out how hate incidents might be sensed and leave behind visceral perceptions that remain outside a distribution that carefully guides reporting these incidents towards existing apparatuses of state and policing. In their recommendations, law-enforcement officers rely on the senses to draw and redraw boundaries of advisable actions (Samimian-Darash and Stalcup 2017). Playing out scenarios frames such senses as simultaneously already active, like an insect's antennae, and trainable, like the olfactory nerve of a hunting dog. Here, the senses exist in the pores of the law, determining what can rise to the level of perceptibility and what is common to community (Rancière 2004, 14). Immigrants from India and China play the role of the front-line defenders of this polity, establishing that the state determines the prosecution of hate crimes to be held in common by all citizens. Yet the meetings also capture the sensate, which falls outside both of the sensible and of dissensus, because immigrant opposition does not cohere into dissent.

In interviews I held with participants after this and similar community meetings, I learned that many of them had an immediate, and in their accounts, hard to rationalize reaction to these indignities. The community sessions attempted to give voice to these experiences, even as these sessions shaped that experience through a framework of correct responses.

The sensible describes the way the world is partitioned into what can be perceived, by whom, and how. For Jacques Rancière, the senses exist neither in the biological bodies of individuals nor in the categories of human cognitive faculties. Instead, the senses are distributed across categories and individuals. Rancière names the distribution of the sensible in two ways. First, he describes how the world is divided, or partitioned, to create inclusions and exclusions, determining what kinds of subjects belong in which parts. Second, he articulates how those subjects are deemed to be part of the world - in other words, how they can par- 
ticipate in it (Chari 2015). The exclusion of some sensations from the knowable world constitutes a means of creating a particular distribution of the sensible, one that Rancière $(2010,37)$ might describe as a distribution based on the notion of fittingness, where "society consists of groups dedicated to specific modes of action, in places where those occupations are exercised, in modes of being corresponding to these occupations and these places." Rancière (2010, 149) calls that which lies beyond this distribution "dissensus," which marks a break from the taken-for-granted relationship between what is sensed and what is understood to be real, correct, or natural. This break can ground a different understanding of that which is taken to be real.

Dissensus grounds politics, because politics concerns who is included in the management of common life, and a different answer to the question of who is included in political life emerges from registering a break between who and what are left out from having a say in making decisions in common, and questioning why that is the case (Rancière 2011, 2; O'Connor 2015). But what happens to those lost sense impressions that fall below the threshold of a particular distribution of the sensible yet do not enunciate dissensus?

These lost sense impressions might be called the sensate. Sensate are those sense impressions that pool beneath the self-evident facts of the senses. The distribution of the sensible and of the sensate are yoked. They move through the visceral and the semiotic, and affiliate individuals through a shared - but differently experienced - history of racial formations (Harper 2000; Smith 2006). Taken together, they draw immigrant subjects into an apparatus of rule while registering immigrant exclusion.

\section{HATE INCIDENTS, NOT HATE CRIMES}

Of all the scenarios presented in the Salish Flats Middle School gym that day, only one rose to the level of a possible hate crime: the incident where a woman feared for her safety as she was tailgated. Hate crimes are prosecuted in Washington State under the Felony Malicious Harassment Statute (RWW 9A.36.080). The law extends to race, color, religion, ancestry, national origin, gender, sexual orientation, or mental, physical, or sensory handicap. The acts that can be prosecuted under this law require maliciously and intentionally committing either physical injury or property damage or reasonable fear of harm to person or property. Yet the act cannot consist of words alone. "It shall not constitute malicious harassment for a person to speak or act in a critical, insulting, or deprecatory way so long as his or her words or conduct do not constitute a threat of harm” (RWW 9A.36.080). ${ }^{6}$ 
During the meeting in the spring of 2018, the assistant U.S. attorney, who leads the Department of Justice for Washington State's Hate Crimes Task Force, admitted to having seen a spike in hate crimes in the previous few months. A second assistant U.S. attorney then clarified how the law approached these crimes. First, he said, there had to be an actual attack or threat. Second, there had to be a motive, which was often difficult to prove. He continued that when reporting a hate crime, one should take note of details that can show motive. For example, tattoos could evince membership in a particular organization; or discriminatory intent might be concluded from certain bystanders being spared.

According to the schema of state and federal legislation, hate crimes are actions motivated by racial, sexual, or ability-based animus. Hate incidents, on the other hand, are similarly motivated but do not constitute a threat of harm - that is, a reasonable person would not intuit harm to person or property. ${ }^{7}$ Reports of hate incidents form part of a police surveillance apparatus and help create a profile of a potential act; of themselves, however, they are not registered as worthwhile reports. Police collect reports of such incidents so they can establish a profile of possible hate. Materials gathered from hate incidents are entered into police records; they include a description of what happened, the location, and the people involved. These records become part of a database of known incidents.

Immigrants thus become absorbed into the fingertips, nose, and skin of the state. Their senses create a skin that can perceive the legal out-of-bounds of right radical extremists even while immigrants learn to recognize the boundary between acceptable and unacceptable modes of expressing rage, between out-ofbounds conduct and protected speech. The training sessions coached potential victims in how to pick up and record the indexes of hate to establish patterns, even while leaving the reports themselves and their embodied effects unacknowledged.

Immigrant bodies move across a field of struggle in the everyday spaces of suburban IT enclaves. Tech economy geographies encompass what Gloria Anzaldúa (1987) has described as a frontier, where landscapes are crossed by experiential regimes of belonging and displacement, limited inclusion and threat. While many workers reported feeling safe and welcome in their corporate offices, even if they recognized that their visa status constrained their career trajectories, outside the office doors many felt unsafe and unwanted. In these frontier places, hate incidents also record intimidation campaigns that simmer just below the level of viable prosecution.

Bringing an analysis of racial capital to bear on how immigrants are trained to respond to hate even while they are evaluated as differentially desirable working 
bodies reveals the stakes and the limits of immigrant solidarity in the current age of distributed contempt. To make this theoretical move between extant theorizations of the politics of the senses and those of racial capital, I next offer a methodological approach to the senses that takes processes of racialization into account. This methodology grounds a further discussion of migrants' varied responses to the particular distribution of the sensible.

\section{THE DISTRIBUTION OF THE SENSIBLE AND THE SENSATE}

The senses-how one perceives the way something looks, smells, feels, tastes, and sounds - have been marshaled at least since the European Enlightenment to determine what a person can know and who can know what. These questions were fundamentally bound up with establishing the humanity of the Enlightenment's racialized and gendered others (Wynter 1989; Vora and Atanasoski 2015). Along the way to establishing the natural rights of man, John Locke (1689), for example, determined the contours of human rationality by recourse to the idea that correlations between the senses and concepts could be taught. Locke separates true from habitual sensations by means of distinguishing proper and improper associations and writes of the need to separate "natural" from "acquired antipathies." Falsely acquired sense impressions, Locke suggests, could be extremely dangerous, especially when formed early in childhood. The "wrong connection" of ideas "is of so great force to set us awry in our actions" as well as in our "morals, passions, reasonings and notions themselves" (Locke 1689, 1). Improper associations arise from chance, training, and repetition; it is up to trained judgment to reject them (Locke 1689; Kallich 1945, 308).

Locke put the distinction between natural and wrongheaded associations, along with the practice of training the senses, at the heart of his moral and rational theory of the limits of human understanding. In doing so, he and other political philosophers (like Thomas Hobbes before him and Edmund Burke after him) participated in a discussion about the capacities of discernment that would endure throughout European colonial expansion. Such debates on human understanding left open the questions of whether being afraid of some kinds of people was natural or whether colonial subjects and women could be trained to overcome their own "false" impressions.

Though the literature linking colonial subjects to the senses is vast, such reasoning perhaps reaches its apotheosis in Frantz Fanon's (2008) account of living as a black colonial subject in Paris, the colonial metropole. In a famous passage from his Black Skin, White Masks, which chronicles Fanon's realization of his inhuman- 
ity in the eyes of French colonists despite his credentials and his language, Fanon recounts a French child's terror when faced with, in the child's words, "a negro." When the two meet on a train, Fanon shivers with cold and the child trembles with fear. Under the false impression that Fanon is quivering with anger, the child jumps into his mother's arms, exclaiming, "Mama, the nigger's going to eat me up" (Fanon 2008, 86). Fanon's description records both the child's sensations at seeing Fanon and his own reaction at experiencing this terror. Fanon evokes the sensate by mirroring the child's trembling and his own shivering against the cold. These shudders echo further as Fanon traces the physiological and psychological effects of colonial rule from the Antilles to Algiers. It is only in the conclusion of Black Skin, White Masks that Fanon manages to move the sensate that he has recorded on multiple occasions throughout the text into dissensus to inaugurate a new human condition. "Oh my body," writes Fanon $(2008,131)$ in his final prayer in the book, "make of me always a man who questions," thereby moving together with the very specificity of the body and its registers of the sensate toward a continually expansive new humanity.

In Fanon's writings, the direct experience of European colonialism and anticolonial struggle bookend colonial subjects' experiences of hatred. In contemporary suburban technical enclaves, the distribution of the sensible and the sensate tells a story of immigrant shock as the politics of labor loop over and contradict themselves, revealing the immigrant coder as both wanted tech worker and unwanted foreigner. In these spaces inside and outside of state jurisdiction, immigrants are drawn into becoming the subject of sensory terror even while they are asked to make fine-grained distinctions based on their own sensibilities.

Community members experienced these bias incidents in multiple ways. Their reactions should inform discussions of immigrant sensibilities and the political possibilities precipitated therein. In other words, while existing models of the sensible take the politics of dissent as the outcome of democratic state organization, I found that the repartition of sensation Rancière calls for requires work, without which dissensus can pool in disorientation rather than dissent. This may hold especially true in tech enclaves, where campus design, contract labor practices, and engineering cultures, which historically emphasize narrow problem solving over big-picture analyses, expressly push to the margins political dissent (Forsythe 2002; Bacon 2011; Srivastava 2015). When a person like Philip experiences harassment, he gathers up his sensibilities, records them, and reports on them. What happens next, though, can only be recognized through the lens of the particular racial formation that organizes his immigrant labor. 


\section{DOG POOP POLITICS}

The first time I saw Philip Chen, he stood before a crowded room in the local cultural center during a harvest festival. His hands were shaking. In a strong voice that belied his trim frame and his slightly stooped bearing, Philip outlined how he had taken his reports of racial harassment to the local city council only to have his complaint fall on deaf ears (Ahmed 2018). He was desperate for help; the room stilled after he had spoken. Someone directed him to the local American Civil Liberties Union (ACLU) representative, who would strategize with him after the meeting. Philip had been sitting next to me, and I explained that I was an anthropologist studying hate crimes in the Seattle area and asked if we could meet. Two weeks later, we found ourselves sipping overheated herbal tea from oversized paper cups at the Panera Bread Company.

Philip described for me months of harassment in detail. He had been followed home from work. He had had dog feces placed on his lawn. He had had car lights shone through his living room window. After chronicling these events, he asked for my pen, and drew for me the winding road that ends at a cul-de-sac where he lives. "It is impossible," he said, "that anyone would be parked and waiting on that street for any other reason but to harass me." The street does not lead anywhere else.

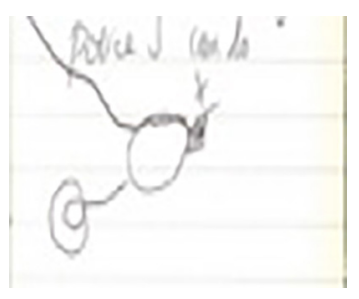

Figure 2. Philip marks my notebook with a map of his house $\mathbf{x}$ and the street he lives on. Taking it back, I noted "police can do" with a question mark in the margins. Image created by Sareeta Amrute.

He then produced his phone. "I bought cameras," he told me, "and installed them on my roof." "But they were cheap cameras from Costco," Philip continued, “and they couldn't capture everything in enough detail." He had uploaded all these videos to YouTube, and we watched a few together. During the first one, Philip pointed out the relevant features to me: a car comes down his street at night. It makes a slow turn, then waits. Its reverse lights blink on. We see Philip come down his driveway toward the car; the car is put in drive and speeds away. The hairs on the back of my neck stood on end as we reached the end of the video. It 
did indeed look like someone was watching his house, the driver using the car's rearview mirror to do so.

In the next clip, we see the line of young pines that mark the edge of Philip's property. A man and his dog enter screen left. The two disappear for a while behind the trees and emerge from the other side, finally moving to the right and out of sight of the camera. The man is letting his dog shit on the edge of Philip's lawn. This goes on, every day, for more than two weeks. Philip stopped the video to offer me further visual evidence, toggling between his online account and his phone's photos. He blazed through dozens of still photographs of dog poop, glistening, wet, curled, and gigantic, now nestled together, in series, on his phone. He scrolled and I nearly retched, the piles' vile odor seeming to emerge from the glass of Philip's handheld screen.

Philip's choice to install video cameras made use of a logic of surveillance that would ultimately disappoint him. He believed that better evidence would produce prosecutable results, but the grainy quality of the video thwarted his desire. Even with perfect picture quality - like that of his dog poop stills — it is debatable that law enforcement could do anything without proof of racial motive. The poop, too, was extruded just beyond the pines that mark Philip's property line and would not count as destruction of property.

While his images failed to elicit the governance response he desired, we may aptly describe them as part of a surveillance culture that has evolved from metaphors of containment over a territory rooted in U.S. Cold War politics to the increased collection of data from individual users by corporate actors (Collier and Lakoff 2008; Mallard and Lakoff 2011; Hu 2016; Gilman and Green 2018; Zuboff 2019). Philip used sousveillance — watching from below - to try to garner state protection, even while his efforts furthered, rather than evaded, the logic of state surveillance through recourse to the police (Mann 2004; Browne 2015). While state actors may be interested in Philip's evidence as a prospective marker about what sites, groups, and actors to pay attention to as potentially dangerous in the future, his call was for immediate action. In that moment, this call was answered only through our shared attention to the seemingly endless series of disgust scrolling across Philip's cell phone screen.

The visceral reactions Philip and I experienced just looking at the pictures of dog poop points toward the senses acting in excess of formal procedures of the law. ${ }^{8}$ The senses become a repository for immigrant communities to track, remember, and train themselves in the practice of detecting white rage. They constitute a site of struggle over spatial borders, a means of training immigrants as 
subjects of the state, and repositories for immigrant communities to call forth encounters that simmer below the level of prosecutable hate crimes. Despite his video archive, Philip continued to be frustrated as his reports remained with the sensate, never grounding political agitation on a larger scale.

\section{THE SENSATE}

The senses can be discounted as insignificant, too small to garner social attention. They can be subject to "numbing and erasure" (Seremetakis 1994, 23), especially when they elicit reactions that fall outside of an accepted distribution. As Lalaie Ameeriar (2017) argues, for immigrants, evidence their senses are trained to notice is complemented by what their bodies are trained to produce, a sanitized sensorium stripped of smell, voice, and alterity. Between the labors of recording the significant sensory perceptions necessary to maintain the rule of law and suppressing the ostensibly intolerable immigrant sensorium of smells, looks, and sounds, the sensate gathers in swirling eddies of discontent.

A programmer from Calcutta who has been working for a large software company for the past fifteen years and has lived on Seattle's Eastside told me she had never been racially assaulted; that is, until this year. While taking out the garbage in front of her house, a passerby, whom she believes to be a neighbor's friend, looked her in the face, and said with a smile, "we've got a new president now, you'll have to leave." Then he walked away. The programmer was so shocked, she said nothing, instead, turning up her drive and hurrying inside. For the following three days, she could not leave her house. She would sit at the window and peer in all directions through her half-shut blinds before pacing again up and down the length of her narrow front hall. "I was ashamed," she confided; "I felt shame that something like that could happen to me. And I felt ashamed that I could not even react." When she finally managed to leave her house, she got in her car, backed down the driveway, and drove as quickly as she could to her office. Another young woman, who was born on the Eastside, found herself tailgated as she drove home from a gas station, her four-year-old strapped into a car seat behind her. The pursuing car eventually accelerated past her while the driver screamed at her: "Bitch!" When she reported the incident on a local radio talk show, the deejay accused her of exaggerating the encounter to play politics in a local election because she had hosted a fund-raiser for one of the candidates.

These and other encounters do not bear the structural weight of institutional discrimination; they are smaller matters. They also tend to be sidelined within populations scattered across tech enclaves. "The Indian community," an organizer 
with Amrita's group tells me, "tends to treat these hate crimes by sweeping them under the carpet. They do not want to acknowledge that these things are happening and they do not want to complain." Sometimes, these denials orchestrate proof that these Asian tech workers are different from and superior to other immigrants; sometimes, the fear of deportation quiets complaint. The scattered nature of these encounters reemphasizes suburban enclaves as racialized spaces (Lipsitz 2007; Mankekar 2015). As I have argued, when such incidents fall below the threshold of hate crimes, the possibility for dissensus drops into the sensate, even while the state relies on immigrants as first recorders of hate to set patterns for surveillance and prosecution.

The sensate ebbs beyond the fittingness of action, place, and being that Rancière describes. Rather than grounding dissent, it often pools to assert consensus within an already given distribution, or remains uncaptured, triggering disorientation. Rancière overlooks the crucial place that race holds in cementing the two sides of capital in its current formation - speculative value and graduated labor organization - and therefore cannot recognize how the senses might be channeled into upholding the privilege of difference in global economies, where creativity becomes a clarion call for asserting superiority. While Asian labor becomes a convenient alibi for asserting white privilege, the IT worker's status as needed talent can become a means of asserting migrant hierarchies within and across diasporic communities. As Nicholas De Genova $(2007$, 114) writes about the experience of Mexican migrants in Chicago, migrants' "most visceral sense of the meaningfulness of their experiences as Latina/os," including discrimination and "manifold racializations," both reflect and potentially transform "their subordination as labor for capital.” The question of how the migrant sensate might pierce the distribution of the sensible - and whether, when it does, it upholds settler colonialisms - troubles many immigrant communities.

\section{SENSING SOME VARIETIES OF RACIAL CAPITAL}

When the state fails to act on the hatred it has trained immigrants to record, their senses - already developed to register disgust and loathing-become the grounds for multiple logics of articulating migrants to regimes of capital. One particular gathering brought forward how the senses emerge to reveal the Asian high-tech immigrant as multiply located within their own imaginaries of tech economies, diasporic upper-caste South Asian communities, and national anti-immigrant American politics. 
This session also began with people recounting the kinds of discrimination they had experienced. Amrita was again at the helm. After she introduced the speakers, she began by telling the story of another woman who wanted to remain anonymous. Walking through a nearby shopping center, this woman was speaking with a friend when she was suddenly pushed to the side. The pusher began imitating her speech in what Amrita termed "a very derogatory way." The woman stood still, unable to do anything. It took her fifteen minutes to recover. As Amrita continued the narrative, she underlined that this kind of encounter was a daily occurrence. "Racism,” Amrita intoned, “doesn't know the color of your skin.” She continued, "people work fifty to sixty hours a week and give this nation their life, but they don't even know if they will ever be able to vote in this country."

This introduction contained the many contradictions that would play out over the course of the evening. Amrita called on her audience to recognize that Asians, too, could fall victim to racism_- even though some South Asians believed that educated Asians like themselves would remain immune from racism because they were not Black. ${ }^{9}$ Her message was framed against the common denials that Amrita hears among Asian immigrants in this area, that only Black and Latinx populations are targets of racism, and that Asians, who work in prestigious, high-paying jobs and come from what they consider good, often upper-caste and middle-class backgrounds, are largely spared vitriol. Amrita's call - to recognize an experience of racism across ethnicity_oriented the fear of the shopping mall to a shared political horizon with others. But Amrita also distinguished among victims of racism. Asian immigrants - at least those sitting in the room near Microsoft's campus that evening — worked hard. Yet that work did not translate adequately into political recognition. This latter message oriented immigrant senses in an entirely different way, toward separating Black and Brown bodies according to their training, their class position, and their work ethic, undoing much of the potential for thick solidarity the session was trying to build (Singer 1972; Weber 2001; Liu and Shange 2018).

Amrita then handed over the microphone to the emcee for the evening, a young man named Ajay who had grown up in the United States and had been a temporary visa holder before attaining Green Card and, later, citizenship status. She introduced him as well positioned to moderate between the issues of hate incidents, school bullying, and visa laws because of his background. Ajay introduced the four police chiefs of the surrounding Eastside towns; they came to the front of the green-carpeted room. In their introductions, they emphasized their own immigrant backgrounds. One mentioned his Hispanic wife and that his children 
had experienced bullying at school. In their presentations, the chiefs did their best to account for what they saw as the causes of hate and to counsel the audience on their possible responses. The police chief of the town closest to the Microsoft campus told the audience, "courage is resistance to fear, not its absence." He also urged audience members to remain alert to the dangers of intervention. The audience should know the signs of racism escalating into violence and be ready to call 911. They should not engage if they felt the assailant was focusing on a hijab, a transgender body, or another touchtone for violence. Instead, the chief counseled de-escalation by slowly getting the person harassed away from the harasser. "Do not touch, do not argue with the harasser," retreat to safety. "Most of the people in this room are aware of what happened in Portland," the next chief said before putting up her slide. It displayed a list of warning signs of someone who might turn from verbal to physical violence: the thousand-mile stare, nonsensical speech, pacing. I looked around the room, unsure if most of the assembled knew of the good Samaritan stabbed to death on a train in Portland after stepping between a harasser and three young girls in hijab. Reactions were intent and watchful, if relatively quiet.

After the chief's warning, representatives from the U.S. Attorney General's Office outlined the differences between hate speech and hate crimes, and, as they had at earlier meetings, emphasized the wrong but non-prosecutable nature of hate incidents. They stressed that hate should not exist but happens often, and they urged victims and bystanders to report what they saw, to come together in support groups, and to speak up and speak with one another to combat fear and isolation. One representative mentioned the historical and geographically relevant example of Japanese internment, ending this part of the evening by calling for action: "If we remain silent, the evil that exists is going to get worse. This is an opportunity to stand up, unite, and make a great country."

These messages again urged immigrants to be in solidarity with minority groups and each other and implicitly distanced the attorney general's office - in short, the everyday state-from the xenophobic discourse emerging from the state at the level of the executive branch. Yet in what followed, these messages devolved in a discussion of visa law that separated migrants from one another along the lines of valued speculative capital and devalued labor.

Two representatives from a coalition called Green Card Reforms moved to the front of the room. They expressed concern about the mismatch between the number of $\mathrm{H}-1 \mathrm{~B}$ visas granted yearly and the number of Green Cards granted, the latter subject to a per-country quota. The speakers broached the topic by posing 
a question. "How many of you have gone to a restaurant and been made to wait?" After a pause, the first speaker said, "Now, think if that wait is going to be life changing? That is more than just annoying." The speakers took turns elaborating. As of 2018, they reported, 300,000 people were waiting for a Green Card in the United States. For the speakers, this wait meant discrimination. "Our mistake," asserted the next speaker, "is being highly skilled and learned. We are the ones who come and fix the snafus of the government and corporations. We believe in the country, but the country is not ready to believe in us! What is the mistake we have done? We are law-abiding, paying taxes, helping the economy grow. It should be first come, first served." The first representative spoke of the group's frustration with congressional lobbying. "Senators ask, why don't you go back to your own country? But, there was a need and an opportunity, we are not taking away their jobs. No one was born here except the Red Indians."

An audible groan ricocheted around the room at this last comment, and the emcee Ajay quickly made his way to the front. He masterfully turned the conversation toward shared political goals. "We're all in this together," he declared, "it's not about splitting us up. We need to improve processes together; it is not about who gets served first." Enthusiastic applause surfaced in many corners of the room, and Ajay continued, "We also need to use respectful nomenclature. I would like to take this opportunity to correct the previous speaker: the preferred term is Native American."

In the parking lot after the meeting concluded, clusters of people stood together talking about the event. In my particular cluster, consensus described the Green Card Reforms group as unprofessional. This group of five thirty-something men and three women concurred that they should have included an American citizen in their group presentation to avoid the terrible mistake about "Red Indians." One woman opined that the group failed to understand the nuances of American politics. They all found it embarrassing and agreed that such public gaffes could only hurt the cause of getting more Green Cards issued to citizens from India. Perhaps the session was haunted by the multiple erasures evidenced by the Native place names that dotted the surrounding landscape. ${ }^{10}$

This group recognized that the American political scene was complex and needed "native" know-how. They began to trace in their discussion the complicated terrain that placed them in possible solidarity with other racialized groups, even while dominant narratives enrolled South Asian immigrant engineers into the protectionist and purist regimes of racially exclusionary suburban landscapes (Lipsitz 2007, 12-13). In these exchanges, migrants began working out possible 
distributions of the sensible against a structured mode of racializing labor that runs along the seam between creative and distributed work.

The concept of racial capital elucidates the way ideas about the characteristics of populations are used to justify current relationships of power (Robinson 2000). As Robin D. G. Kelley (2015) argues, investment in a particular idea of power is shifting and needs to be remade constantly. "In the last century alone," Kelley (2015, 334) writes, "racial regimes have been remade, reconfigured, destabilized, and consolidated many times, employing new technologies to circulate old racial fabulations and new fictions in the process of capitalist expansion." The documents that the Green Card Reforms group circulate offer one piece of evidence of a remade racial regime that both devalues and overvalues Asian coding labor.

A bar graph from the group's website demonstrates the many contradictions of Asian labor in coding economies. It compares the number of employment visas and Green Cards issued for India and all other countries and shows that the number of temporary visas vastly outnumbers Green Cards. According to the graph,

\section{Path from employment visa to Green Card is blocked for Indian applicants}

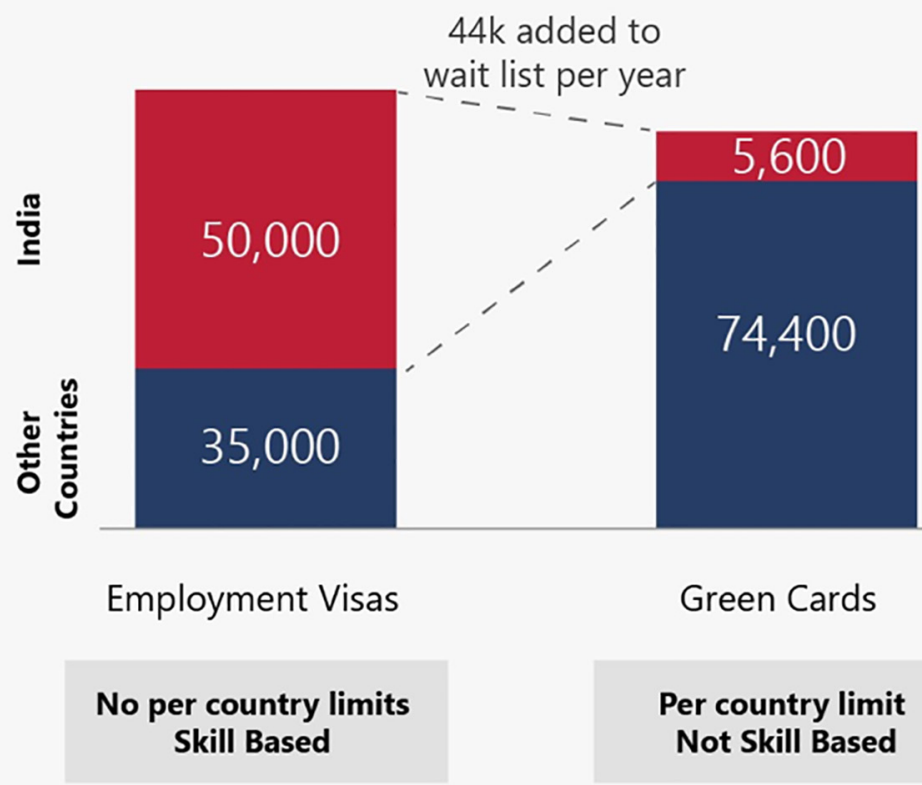

Figure 3. Green Card reform chart. https://www.gcreforms.org/. 
other countries receive many more Green Cards than Indian citizens. Its comparison slyly shows how tech companies rely on replaceable labor as a means of flexible control over workers by using employment visas to fill these substitutable roles. The argument for Green Card mitigation that it also illustrates, however, pits "Indians" against "all other" Green Card holders by showing that Indian citizens receive a small share of Green Cards. In portraying the Green Card problem in this way, it places Indian applicants over all others as worthy of receiving permanent visas, thereby extending tech industry dominance into an analogous argument for Indian dominance in migration policy, even though tech companies themselves benefit from keeping immigrant programming labor circulating in and out of jobs as needed through temporary visas.

This refrain of Indian high-tech, high-caste exceptionalism echoed across many conversations I had about visa rights over the following several months. Most of the people I spoke with that night had internalized the broad strokes of what the Green Card Reforms group presented - that upper-class and upper-caste Asian labor differed from other migrant labor on the side of creative and speculative capital rather than on the side of devalued, segmented work. Often prefaced by a disclaimer declaring that what was coming next did not mean to disparage other groups, statements mostly ended by suggesting that it was unbelievable that well-educated immigrants working in the software industry had to wait longer for permanent rights of residence than other groups. One example I heard several times involved Uber drivers who, according to this discourse, held less value for the economy or society than highly educated immigrant programmers. Here, the speakers drew on a racial imaginary that divides types of immigrants according to the economic exchange value they produce and an industry logic that elevates creative effort over physical labor, separating out those who "just drive" from those who make the apps that manage driver labor. In these conversations, immigrants actively racialized capital by over-valorizing Asian upper-class and upper-caste subjects through the language of merit and cognitive labor and by devaluing other immigrant and Black bodies (Lye 2004; Subramanian 2015).

These narratives suggest that learning to produce out of the sensate a different partition of the sensible requires what José Esteban Muñoz (2007, 447) calls being "attentive to the psychic vicissitudes of our belonging in difference." While Amrita and others hold sessions that attend to this varied landscape of "polyvalent" racial formations, state- and extrastate-making practices that rely on an immigrant sensorium undercut these attempts to sustain and care for that belonging (Stoler 2017). They do so by treating immigrants as first recorders for a judicial apparatus 
that neither can hold economic rationalities accountable nor can help build solidarities through differences (Amrute 2019).

\section{THE SENSATE UNBOUND}

But what seems fundamental to me is to discern whether the state limits itself to taking the minimal steps required of it or if it is really providing, in a wider sense, the means for another form of expression, for another expression.

-Jacques Rancière

The distribution of the sensible and the sensate follow the pathways laid down when the legal regulation of migrant labor traverses tech-industry geographies of personhood and infrastructure (Chun 2011; Amrute 2017). Technical capabilities grant Asian coders entry to global corporate workplaces, but also mark them as foreign workers who can become targets of racial exclusion. These factors define the racial schema that at once includes "Asian" immigrants as wage-suppressed cognitive laborers and excludes them as fleshy representatives of alien capital (Robinson 2000, 2001; Amrute 2016; Day 2016). At the fulcrum of these tendencies in capital and its technical worlds, hate incidents both wind immigrants closer to sociotechnical racial schemas and unwind them from occupying a safe place within them.

Immigrant subjects can become stuck within an existing distribution of the sensible, unable to lift from the sensate the political possibility of dissensus. One kind of stickiness results when immigrant reactions coagulate in the familiar vessels of superiority and inferiority, good and bad immigrants. This stickiness remains within a distribution of the sensible achieved in state rhetoric, visa legislation, and everyday conversations that elevate tech workers above other categories of immigrant (Xia, Wu, and Ye 2018). ${ }^{11}$ Here, the sensate constitutes a subterranean clot of resentment that feeds further divisions among kinds of immigrants and cements tech industries as apolitical and meritocratic. Another kind of stickiness puts immigrants within a closed loop of pressing for relief based on evidence of daily hatred, then finding that this proof of their senses goes largely unheeded. This stickiness suspends subjects within a sensate without outlet.

When next I meet Philip at our unremarkable coffee shop, he told me that his experience of harassment and the techniques of countersurveillance he had employed unearthed an old demon. When he was a younger man in Taiwan, he used 
to hear voices and remember his past lives. By the time he enrolled in university, he was regularly experiencing out-of-body moments in which he felt taken over by spirits. Possession had started happening again in his current home, sometimes when he was up at night waiting for a car to come down his street, sometimes when he was reviewing the video footage from his rooftop cameras. Near the midpoint of our conversation, Philip's eyes flickered to the side and he began chanting softly to himself. Taking my pen in his hand, he jotted down several characters, top to bottom, right to left. After a few minutes the reverie ended, and he told me he could no longer read the words he had written. He then took my palm in his hand and read its lives, but what he saw there was dark and full of death. It unnerved me.

We went back to our conversation about his children for a few moments before we parted ways.

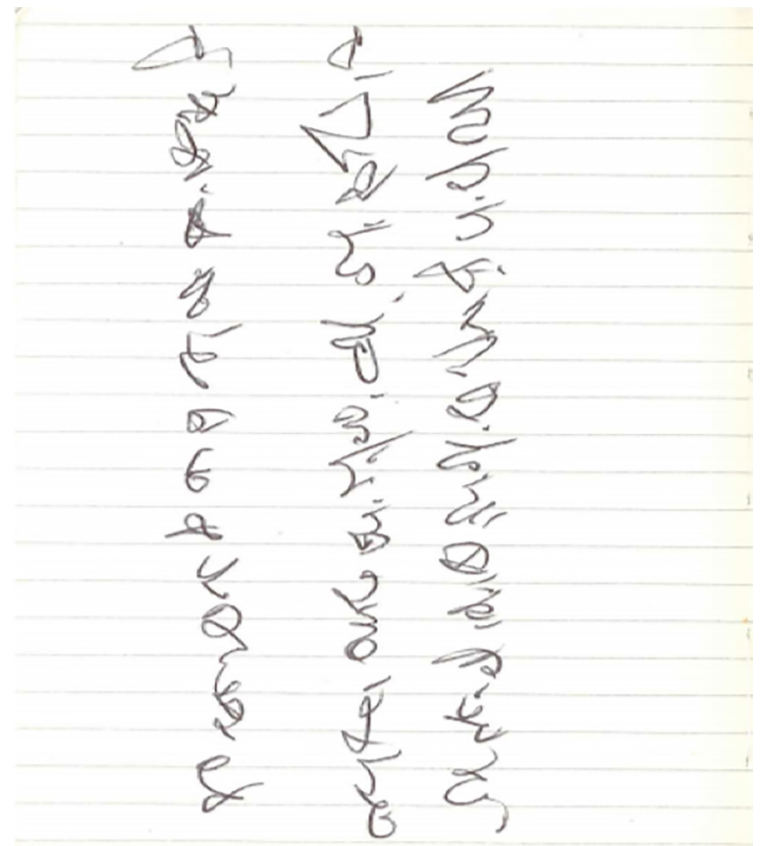

Figure 4. Philip's automatic writing. Image created by Sareeta Amrute.

Philip's writing joins his collection of dog feces stills and nighttime videos in an ever-expanding collection of automatic recordings with no just apparatus to order them. Like an automaton, Philip records in a trance, unable to make meaning of his language of the sensate (Liu 2010). His sensate, now unbound, exceeds the normative sensible laid down all around him. 
Philip, an immigrant positioned at the sensitive fingertips of the state, helps produce the sensing state that maintains the boundaries of acceptable and unacceptable action toward foreign labor, even while it extends its dominion through immigrants' surveillance. Through Philip's ability to track the smell, sound, look, and feel of hatred, state officials produce patterned accounts of when and where curiosity bleeds into malevolence with intent. Yet for all its deployment as an apparatus of state, the evidence of Philip's senses is discounted in a legal regime that sequesters it within the distinction between harassment and hate crime. It is in the failure to redress wrongs done to communities through hate speech that one of the most meaningful - yet underappreciated - artifacts of the politics of hate emerges. The sensate as remainder would need to be rearticulated through a politics of immigrant solidarity that moves beyond procedures of formal recognition of the protection of immigrants as hardworking aspirants to holding property as well as beyond the regime of racial capital that distinguishes bodies in terms of their utility to tech-industry needs for highly skilled yet docile migrant labor (Harris 1993). For Philip, this lack of redress reawakens a spirit that moves the sensate to speak through him, to give an account of that which is neither within a given distribution nor the sensible_-nor constitutes dissensus.

In Rancière's (2004, 13) elaboration of democracy, the starting point of a transformative political project lies in "understanding that the self-evident facts that structure the relations between saying, seeing, and doing themselves belong to the structure of domination and subjection." In democracy, activists should also be flaneurs, and those who narrate should also be those who work, so that the sensible becomes disrupted and boundaries blur between "those who act and those who look; between individual and members of a collective body" (Rancière 2004, 19). Yet beneath or alongside this understanding, an extra part of the work of undemocratic politics, akin to extrastatecraft, is the capture of understanding: it finds no outlet in disruption, but instead coheres into an enduring experience of what can be sensed but not acted on - the sensate.

In studies of divination in Taiwan, scholars like Stephan Feuchtwang (2007) and Shu-Wei Hsieh (2016) note that spirit possession is used commonly to treat ailments and alleviate suffering through spirit mediums. These rituals of divination often include a medium who writes out talismans, prescribes herbal treatments, and uses question-and-answer sessions to communicate with the gods (Hsieh 2016). Such moments of possession attempt to initiate successful communication between humans and a power greater than humanity, deploying narrative structures of invitation, address, and response, followed by thanks and separation. 
Feuchtwang $(2007,62)$ calls this narrative structure a performative invocation of "the human capacity for harmonizing the relation between Heaven and Earth." As he notes, the responses of heaven can be capricious, they may accept or reject an offering, or they may simply laugh in the face of human striving, and demand the ritual's repetition.

Philip's writings in my notebook might be understood as a talisman that records an offering to the gods, and is to be used to protect us both from forces of hate that remain unpropitiated through the mediums of visual capture and legal appeal. Even as Philip's writing records the failure of dissentual politics, it also expresses an attempt to move beyond the impasse of state-as-mediator. Perhaps in recognition of the need to move beyond Washington State-after several further incidents in which Philip engaged in automatic writing without being able to remember what happened, and after several more hours of uploaded video footage too grainy to establish much-Philip's wife floated the idea of a move to California, where she hoped Philip could be free of his hauntings. California might provide the gratitude and separation Philip needed, marking the successful completion of this ritual to change his fate. Though I am skeptical that a move downcoast will free Philip and others like him of harassment, possession registers how undone Philip has become by the failure to find redress through state apparatuses.

In tech enclaves, repeating, mobile, and continually updating forms of life appear to create work places set apart from the messiness of political life (Easterling 2014; Sauter 2019). When the messiness of hate incidents penetrates these spaces, they reveal the interconnectedness of corporate and state dominions across transnational landscapes. The tech landscape in India has its own repeating forms of separate campuses and gated housing communities, emphasizing the separate and global status of the programmers who move between this landscape and similar topographies in the United States and elsewhere (Aneesh 2015; Srivastava 2015; Amrute 2016). In the United States, officials act to protect the suburban communities of workers who at once signify community commitments to diversity and a flexible workforce necessary to producing surplus value. Yet the temporality of these protections is uneven (Mankekar 2015). Within regimes of extrastatecraft, tech workers from India and China both benefit and receive inadequate forms of protection from the racial logics that both transnational corporations and nation-states have produced. Indian and Chinese tech workers set themselves apart from undocumented and Black rights movements, as well as from anti-Wall politics and agitations against the Muslim ban, further entrenching historically established colorist, religious, and caste prejudices in both these countries (Prashad 2001; 
Parameswaran and Cardoza 2009; Rao 2009; Yeung 2015; Chung 2016; Amrute 2017; Byler 2018). An account that centers the sensible and the sensate can record the fragmented histories of capital-colonial expansion that have shaped local geographies, along with a specific state's response to capital formations.

Will the sensate ever be received as an invitation to another expression, as Rancière suggests? Perhaps, but as Amrita can affirm, it cannot happen through simply admitting that the sensible is particularly partitioned, and registering that some sensory evidence goes unrecognized. A new political expression for immigrant politics around the tech industry has to be cultivated across its legal regimes and organizational forms, designed legislatively and organizationally to keep dissensus at a distance.

\begin{abstract}
Seattle and its environs are home to more than eighty tech companies, which have added 780,000 new jobs between 2014 and 2019. Along with these jobs comes increased immigration, especially from India and China. Some of Seattle's Eastside areas now rank among the most diverse in the nation, even while the Pacific Northwest bears a legacy of white supremacist agitation. This essay explores the relationship between the Eastside's tech industry, migration, and what the Attorney General's Office of Washington State calls "hate incidents" — verbal attacks and harassment against minorities that do not rise to the level of hate crimes. I show how forms of evidence about hate incidents circulate in Asian immigrant communities. Victims of these hate incidences track evidence of racial bias simultaneously through material evidence, such as dog poop left on front lawns, and through organizing sense impressions to recognize a shouted slur as racially motivated. This sensory evidence falls below what Jacques Rancière calls a particular distribution of the sensible. I call these lost impressions "the sensate," to capture how the theory of the senses developed by Rancière and others moves too quickly from distribution to dissensus. Instead, the idea of the sensate tracks the ways in which immigrants align, distance themselves from, and register the larger technical and economic scenes in which their lives unfold. [race, immigration, code, tech worlds, distribution of the sensible, the sensate, Rancière]
\end{abstract}

\title{
NOTES
}

Acknowledgments I would like to thank Chris Nelson, Meg Stalcup, Lilly Irani, and Michelle Beckett for providing valuable feedback on this essay. Early versions of this work were presented at the American Anthropological Association annual meetings, where Bruce Grant provided useful commentary and Simanti Dasgupta insight and encouragement; and at the Center for Internet Technology Policy at Princeton University. 
1. According to FBI records, hate crimes against Muslims have increased by 19 percent, against Sikhs by 17 percent, and against Hindus by 100 percent since 2015 (Trivedi 2017).

2. Prosecutable hate crimes must show bias against a person because they are a member of a particular group, demonstrate intent to harm or instill fear, and must include injury to a person or to physical property.

3. These geographies are marked by recent histories of white supremacist movements such as the Northwest Territorial Imperative, an immigration initiative begun in the 1970s designed to colonize Washington, Oregon, and Idaho as a white ethnic state (Crawford 1994; Gallaher 2000).

4. For an excellect overview of the concept of racial capitalism, see Walter Johnson (2018).

5. For an insightful take on American conversational styles, see Jane H. Hill (1998).

6. The Washington State law is broader than the Federal Law on Malicious Harassment because it covers property damage. The federal law includes interfering with someone's ability to exercise rights, including the right to housing and voting.

7. For a review of the concept of the reasonable person in criminal law, see the Lewis and Clark Law Review's (2010) "Symposium: Who Is the Reasonable Person?"

8. Dog feces have a long and storied history in sensory border wars. A recent entry comes from San Francisco, where a dog owner called "Tuffy Tuffington" recently started a counterprotest campaign asking all dog lovers to cover a particular field in the city with their pets' feces before a right-wing extremist demonstration was to take place. The demonstration was moved and the counterprotest never happened. Tuffington told the San Francisco Chronicle, "I just had this image of people and dogs participating in civil disobedience” (Rubenstein 2017).

9. For a compelling account of antiblackness and immigration, see M. Shadee Malaklou (2018).

10. The intrusion of the term red Indian here marks the salience of the what Eve Tuck and K. Wayne Yang (2012) call the "settler-native-slave" triad to immigrant politics in the United States. Here, that triad is serving to separate worthy from unworthy immigrants based on hard work and simultaneously justifies brown and white settler projects embodied in housing and office complexes on the landscape.

11. Jitu, an organizer and tech worker laboring against caste among diasporic South Asians employed in tech firms, explains this familiar distribution in the case of India by suggesting that for privileged Indians, their entire reason for being has revolved around seeking material goods since import restrictions to India were lifted in 1991. That notion, combined with the image of the United States as a place where, as Jitu said to me, "science and technology allow people to do whatever they want," convinces people to be complicit in the construction of a racial schema that holds Asian labor in place, undervalued as immigrants and overvalued as technical knowledge workers.

\section{REFERENCES}

Ahmed, Sara

2018 "Refusal, Resignation and Complaint." Feministkilljoys (blog), June 28. https:// Ameeriar, Lalaie

feministkilljoys.com/2018/06/28/refusal-resignation-and-complaint/.

2017 Downwardly Global: Women, Work, and Citizenship in the Pakistani Diaspora. Durham, N.C.: Duke University Press.

Amrute, Sareeta

2016 Encoding Race, Encoding Class: Indian IT Workers in Berlin. Durham, N.C.: Duke University Press.

2017 "Press One for POTUS, Two for the German Chancellor: Humor, Race, and Rematerialization in the Indian Tech Diaspora." HAU: Journal of Ethnographic Theory 17, no. 1: 327-52. https://doi.org/10.14318/hau7.1.023. 
2019 “Of Techno-Ethics and Techno-Affects.” Feminist Review 123, no. 1: 56-73. https:// doi.org/10.1177/0141778919879744.

2020 "Bored Techies Being Casually Racist: Race as Algorithm." Science, Technology, and Human Values. https://doi.org/10.1177/0162243920912824.

Aneesh, A.

2015 Neutral Accent: How Language, Labor, and Life Become Global. Durham, N.C.: Duke Anzaldúa, Gloria University Press.

1987 Borderlands / La Frontera: The New Mestiza. San Francisco: Aunt Lute Books. Aretxaga, Begoña

2012 States of Terror: Begoña Aretxaga's Essays. Reno: Center for Basque Studies, University of Nevada.

Bacon, David

2011 "Up Against the Open Shop: The Hidden Story of Silicon Valley's High-Tech Workers." Truthout, March 4. https://truthout.org/articles/up-against-the-openBhabha, Homi K. shop-the-hidden-story-of-silicon-valley-s-high-tech-workers-2/.

1994 The Location of Culture. New York: Routledge.

Bhattacharyya, Gargi

2018 Rethinking Racial Capitalism: Questions of Reproduction and Survival. London: Rowman and Littlefield International.

Browne, Simone

2015 Dark Matters: On the Surveillance of Blackness. Durham, N.C.: Duke University Press.

Byler, Darren

2018 "Violent Paternalism: On the Banality of Uyghur Unfreedom.” Asia-Pacific Journal

Chari, Anita 16, no. 4: 1-15. https://apjjf.org/2018/24/Byler.html.

2015 A Political Economy of the Senses: Neoliberalism, Reification, Critique. New York: Columbia University Press.

Chun, Wendy Hui Kyong

2011 Programmed Visions: Software and Memory. Cambridge, Mass.: MIT Press.

Chung, Brian Su-Jen

2016 "Finding Happiness in the Chinese Suburban Technopolis: White Supremacy in Silicon Valley, California." Verge: Studies in Global Asias 2, no. 1: 58-65. https://doi. org/10.5749/vergstudglobasia.2.1.0058.

Collier, Stephen J., and Andrew Lakoff

2008 "Distributed Preparedness: The Spatial Logic of Domestic Security in the United States." Environment and Planning D: Society and Space 26, no. 1: 7-28. https://doi.

Crawford, Robert $\operatorname{org} / 10.1068 / \mathrm{d} 446 \mathrm{t}$.

1994 Northwest Imperative: Documenting a Decade of Hate. Seattle, Wash.: Northwest Coalition Against Malicious Harassment.

Day, Iyko

2016 Alien Capital: Asian Racialization and the Logic of Settler Colonial Capitalism. Durham, N.C.: Duke University Press.

De Genova, Nicholas

2007 "The Everyday Civil War: Migrant Labor, Capital, and Latina/o Studies." In $A$ Companion to Latina/o Studies, edited by Juan Flores and Renato Rosaldo, 105-15.

Easterling, Keller Malden, Mass.: Blackwell.

2014 Extrastatecraft: The Power of Infrastructure Space. London: Verso.

Fanon, Frantz

2008 Black Skin, White Masks. Translated by Richard Philcox. London: Pluto. Originally published in 1952. 
Feuchtwang, Stephan

2007 "On Religious Ritual as Deference and Communicative Excess." Journal of the Royal Anthropological Institute 13, no. 1: 57-72. https://doi.org/10.1111/j.14679655.2007.00413.x.

Forsythe, Diana E.

2002 Studying Those Who Study Us: An Anthropologist in the World of Artificial Intelligence.

Gallaher, Carolyn Stanford, Calif.: Stanford University Press.

2000 "Global Change, Local Angst: Class and the American Patriot Movement." Environment and Planning D: Society and Space 18, no. 6: 667-91. https://doi. org $/ 10.1068 / \mathrm{d} 269$.

Gilman, Michelle E., and Rebecca Green

2018 "The Surveillance Gap: The Harms of Extreme Privacy and Data Marginalization." NYU Review of Law and Social Change 42, no. 2: 253-307. https://ssrn.com/ abstract $=3172948$.

Halewood, Peter

2011 "Citizenship as Accumulated Racial Capital." Columbia Journal of Race and Law 1, no. 3: 313-25. https://doi.org/10.7916/cjrl.v1i3.2259.

Harper, Phillip Brian

2000 "The Evidence of Felt Intuition: Minority Experience, Everyday Life, and Critical Speculative Knowledge." GLQ: A Journal of Lesbian and Gay Studies 6, no. 4: 641-57. https://doi.org/10.1215/10642684-6-4-641.

Harris, Cheryl I.

1993 "Whiteness as Property." Harvard Law Review 106, no. 8: 1707-91. https://doi. org/10.2307/1341787.

Hill, Jane $\mathrm{H}$.

1998 "Language, Race, and White Public Space." American Anthropologist 100, no. 3:

Hirschkind, Charles 680-9. https://doi.org/10.1525/aa.1998.100.3.680.

2006 The Ethical Soundscape: Cassette Sermons and Islamic Counterpublics. New York: Columbia University Press.

Hsieh, Shu-Wei

2016 "Possession and Ritual: Daoist and Popular Healing in Taiwan." Journal of Daoist Studies 9, no. 1: 73-100. https://doi.org/10.1353/dao.2016.0003.

Hu, Tung-Hui

2016 A Prehistory of the Cloud. Cambridge, Mass.: MIT Press.

Hudson, Peter James

2017 Bankers and Empire: How Wall Street Colonized the Caribbean. Chicago: University of Johnson, Walter Chicago Press.

2018 “To Remake the World: Slavery, Racial Capitalism, and Justice." Boston Review, February 20. http://bostonreview.net/forum/walter-johnson-to-remake-theworld.

Kallich, Martin

1945 "The Association of Ideas and Critical Theory: Hobbes, Locke and Addison." ELH

Kelley, Robin D. G. 12, no. 4: 290-315. https://doi.org/10.2307/2871509.

2015 "Beyond Black Lives Matter." Kalfou 2, no. 2: 330-37. https://doi.org/10.15367/ kf.v2i2.71.

Leong, Nancy

2013 "Racial Capitalism.” Harvard Law Review 126, no. 8: 2151-225. http://dx.doi. org/10.2139/ssrn.2009877. 
Lewis and Clark Law Review, ed.

2010 "Symposium: Who Is the Reasonable Person?" Symposium, Lewis and Clark Law Review 14, no. 4. https://law.lclark.edu/law_reviews/lewis_and_clark_law_ Lipsitz, George review/past_issues/volume_14/number_4.php.

2007 "The Racialization of Space and the Spatialization of Race: Theorizing the Hidden Architecture of Landscape." Landscape Journal 26, no. 1: 10-23. https://doi. Liu, Lydia $\mathrm{H}$. org/10.3368/lj.26.1.10.

2010 The Freudian Robot: Digital Media and the Future of the Unconscious. Chicago: University of Chicago Press.

Liu, Roseann, and Savannah Shange

2018 "Toward Thick Solidarity: Theorizing Empathy in Social Justice Movements." Radical History Review 131: 189-98. https://doi.org/10.1215/01636545-4355341.

Locke, John

1689 The Works of John Locke, Vol. 1 (An Essay Concerning Human Understanding, Part 1). London: Rivington. http://oll.libertyfund.org/titles/locke-the-works-vol-1-anLye, Colleen essay-concerning-human-understanding-part-1?q=maid\#Locke_0128-01_800.

2004 America's Asia: Racial Form and American Literature, 1893-1945. Princeton, N.J.: Princeton University Press.

Malaklou, M. Shadee

2018 "Dilemmas' of Coalition and the Chronopolitics of Man: Towards an Insurgent Black Feminine Otherwise." Theory and Event 21, no. 1: 215-58. muse.jhu.edu/ article/685977.

Mallard, Grégoire, and Andrew Lakoff

2011 "How Claims to Know the Future Are Used to Understand the Present: Techniques of Prospection in the Field of National Security." In Social Knowledge in the Making, edited by Charles Camic, Neil Gross, and Michèle Lamont, 339-77. Chicago: University of Chicago Press.

Mankekar, Purnima

2015 Unsettling India: Affect, Temporality, Transnationality. Durham, N.C.: Duke University Press.

Mann, Steve

2004 “Sousveillance': Inverse Surveillance in Multimedia Imaging." Proceedings of the 12th Annual ACM International Conference on Mulitmedia, 620-27. https://doi.

Muñoz, José Esteban org/10.1145/1027527.1027673.

2007 “'Chico, What does it feel like to be a problem?' The Transmission of Brownness." In A Companion to Latina /o Studies, edited by Juan Flores and Renato Rosaldo, 441-

\section{O'Connor, Kieran} 51. Malden, Mass.: Blackwell.

2015 “Don't they represent us?': A Discussion Between Jacques Rancière and Ernesto Laclau.” Verso Books (blog), May 26. https://www.versobooks.com/blogs/2008don-t-they-represent-us-a-discussion-between-jacques-ranciere-and-ernestolaclau.

Parameswaran, Radhika, and Kavitha Cardoza

2009 "Melanin on the Margins: Advertising and the Cultural Politics of Fair/Light/ White Beauty in India." Journalism and Communication Monographs 11, no. 3: 213

Pearkes, Eileen Delehanty 74. https://doi.org/10.1177/152263790901100302.

2016 A River Captured: The Columbia River Treaty and Catastrophic Change. Victoria, B.C.: Rocky Mountain Books. 
Povinelli, Elizabeth A.

2002 The Cunning of Recognition: Indigenous Alterities and the Making of Australian Multiculturalism. Durham, N.C.: Duke University Press.

Prashad, Vijay

2001 The Karma of Brown Folk. Minneapolis: University of Minnesota Press.

Rancière, Jacques

2004 The Politics of Aesthetics: The Distribution of the Sensible. Translated by Gabriel Rockhill. New York: Continuum.

2010 Dissensus: On Politics and Aesthetics. Edited and translated by Steven Corcoran. London: Bloomsbury.

2011 "The Thinking of Dissensus: Politics and Aesthetics." In Reading Rancière: Critical Dissensus, edited by Paul Bowman and Richard Stamp, 1-17. New York: Continuum.

Rao, Anupama

2009 The Caste Question: Dalits and the Politics of Modern India. Berkeley: University of California Press.

Robinson, Cedric J.

2000 Black Marxism: The Making of the Black Radical Tradition. Chapel Hill: University of North Carolina Press.

2001 An Anthropology of Marxism. Aldershot: Ashgate.

Rubenstein, Steve

2017 “Dog-Poop Protest for SF Right-Wing Rally Site Is Thwarted.” SFGate, August 25. https://www.sfgate.com/bayarea/article/Dog-poop-protest-for-SF-right-wingrally-is-11961403.php.

Samimian-Darash, Limor, and Meg Stalcup

2017 "Anthropology of Security and Security in Anthropology: Cases of Counterterrorism in the United States." Anthropological Theory 17, no. 1: 60-87. https://doi.org/10.1177/1463499616678096.

Sauter, Molly

2019 "Innovation's Fairylands." Book review essay. New Media and Society 21, no. 2: 528 34. https://doi.org/10.1177/1461444818797088.

Scott, James C.

1998 Seeing Like a State: How Certain Schemes to Improve the Human Condition Have Failed. New Haven, Conn.: Yale University Press.

Seremetakis, C. Nadia, ed.

1994 The Senses Still: Perception and Memory as Material Culture in Modernity. Boulder, Colo.: Westview.

Singer, Milton

1972 When a Great Tradition Modernizes: An Anthropological Approach to Indian Civilization. New York: Pall Mall Press.

Smith, Mark M.

2006 How Race Is Made: Slavery, Segregation, and the Senses. Chapel Hill: University of North Carolina Press.

Srivastava, Sanjay

2015 Entangled Urbanism: Slum, Gated Community and Shopping Mall in Delhi and Gurgaon.

Stoler, Laura Ann New Delhi: Oxford University Press.

2017 "The Politics of Gut Feelings." Stevanovich Institute on the Formation of Knowledge, Inaugural Conference. Video, 1:01:28. https://www.youtube.com/ watch?v=MAAX02bg7ps.

Subramanian, Ajantha

2015 "Making Merit: The Indian Institutes of Technology and the Social Life of Caste." Comparative Studies in Society and History 57, no. 2: 291-322. https://doi. org/10.1017/s0010417515000043. 
Takaki, Ronald

1993 A Different Mirror: A History of Multicultural America. Boston, Mass.: Little, Brown.

Takami, David

1992 Executive Order 9066: Fifty Years Before and Fifty Years After: A History of Japanese

Thrush, Coll Americans in Seattle. Seattle: Wing Luke Asian Museum.

2007 Native Seattle: Histories from the Crossing-Over Place. Seattle: University of Washington Press.

Trivedi, Vivek

2017 "Hate Remains on the Rise, According to the FBI." South Asian Americans Leading Together (SAALT), November 15. http://saalt.org/hate-remains-on-the-riseaccording-to-the-fbi/.

Trouillot, Michel-Rolph

2001 "The Anthropology of the State in the Age of Globalization: Close Encounters of the Deceptive Kind." Current Anthropology 42, no. 1: 125-38. https://doi. org $/ 10.1086 / 318437$.

Tuck, Eve, and K. Wayne Yang

2012 "Decolonization Is Not a Metaphor." Decolonization: Indigeneity, Education, and Society 1, no. 1: 1-40.

Vora, Kalindi, and Neda Atanasoski

2015 "Surrogate Humanity: Posthuman Networks and the (Racialized) Obsolescence of Labor." Catalyst: Feminism, Theory, Technoscience 1, no. 1: 1-40. https://doi.

Weber, Max org/10.28968/cftt.v1i1.28809.

2001 The Protestant Ethic and the Spirit of Capitalism. London: Routledge.

Weheliye, Alexander G.

2014 Habeas Viscus: Racializing Assemblages, Biopolitics, and Black Feminist Theories of the Human. Durham, N.C.: Duke University Press.

Wynter, Sylvia

1989 "Beyond the Word of Man: Glissant and the New Discourse of the Antilles." Word Literature Today 63, no. 4: 637-48. https://doi.org/10.2307/40145557.

Xia Lin, Wu Xiaoling, and Ye Zaiqi

2018 "Chinese Engineers Thrive in Silicon Valley." Xinhua News Agency, March 11. http://www.xinhuanet.com/english/2018-03/11/c_137030147.htm.

Yeung, Evelyn

2015 "White and Beautiful: An Examination of Skin Whitening Practices and Female Empowerment in China." On Our Terms: The Undergraduate Journal of the Athena Zuboff, Shoshana Center for Leadership Studies 3, no. 1. http://dx.doi.org/10.7916/D82N51DW.

2019 The Age of Surveillance Capitalism: The Fight for a Human Future at the New Frontiers of Power. New York: PublicAffairs. 